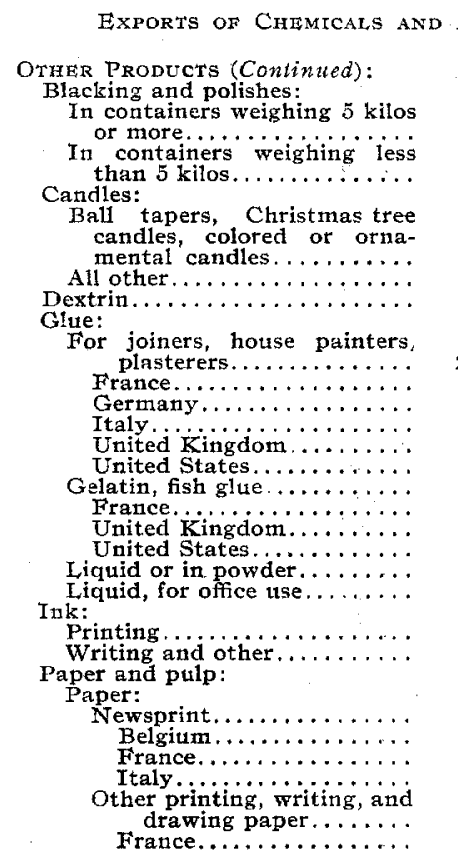

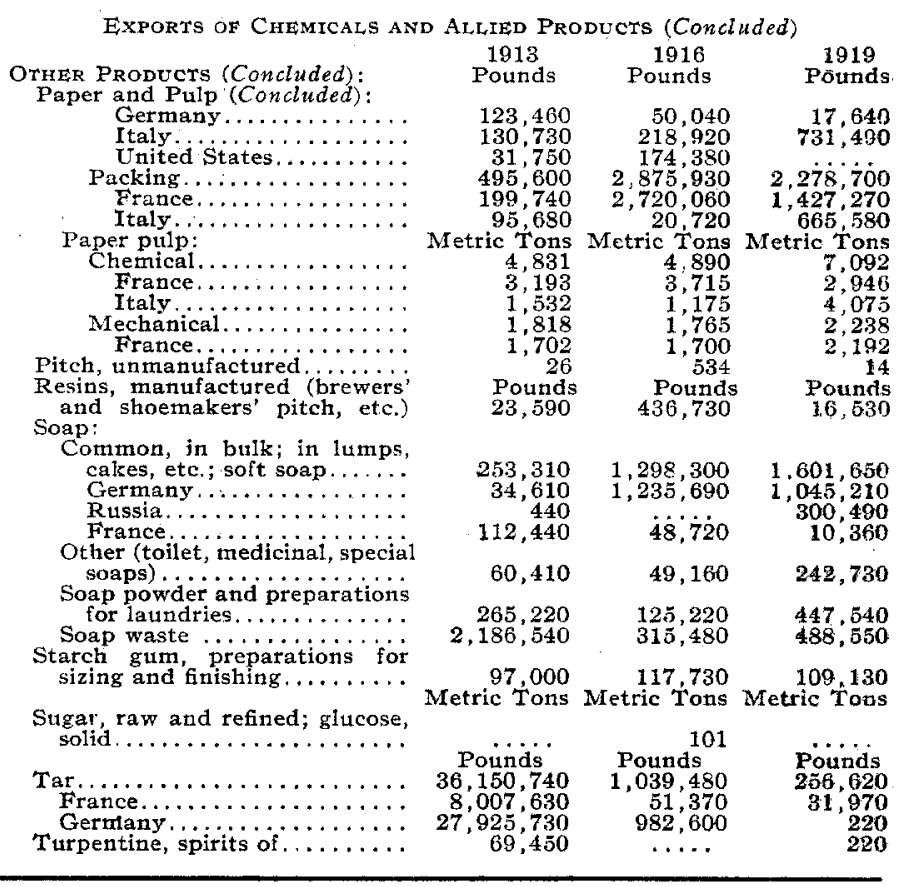

PAPERS
NOTICE TO AUTHORS: All drawings should be made with India ink, preferably on tracing cloth. If coördinate paper is used, blue must be chosen, as all other colors blur on reduction. The larger squares, curves, etc., which will show in the finished cut, are to be inked in.

Blue prints and photostats are not suitable for reproduction.
Lettering should be even, and large enough to reproduce well when the drawing is reduced to the width of a single column of THIs JoURNaI, or less frequently to double column width.

Authors are requested to follow the SocIETr's spellings on drawings, e. g., sulfur, per cent, gage, etc.

\title{
An Application of the Vapor Pressures of Potassium Compounds to the Study of the Recovery of Potash by Volatilization ${ }^{1,2}$ \\ By Daniel D. Jackson and Jerome J. Morgan \\ Columbia Unterersity, NeW York, N, Y.
}

The immense amount of work which has been done upon the extraction of potash from complex mineral silicates is clearly shown by a bibliography on the subject published at the beginning of 1918 by $E$. C. Buck. ${ }^{3}$ This bibliography refers to no less than one hundred and thirty patents and fifty general articles published in the six years, 1912 to 1917 . Of the proposed processes for the recovery of potassium in the form of soluble salts from the natural potassium-bearing silicates fully one-third are based upon the separation of the potassium compounds by volatilization. In spite of this great amount of work and with the stimulus of the inflated prices of potassium compounds, only a very few of the numerous processes proposed have been put into actual operation on a commercial scale. It was decided, therefore, to apply the knowledge obtained from the vapor pressure experiments recorded in a previous paper ${ }^{4}$ to an investigation of the volatilization of potassium compounds

1 Received December 20, 1920.

2 Part of a thesis submitted in partial fulfilment of the requirement for the degree of Doctor of Philosophy in the Faculty of Pure Science, Columbia University, New York, N. Y.

Mel. Chem. Ens., 18 (1918), 33, 90.

- Jackson and Morgan, Thrs JourNal, 13 (1921), 110. from mixtures of silicates with releasing and volatilizing agents. It was thought that this investigation would show the reason for the apparent failure of so many of the proposed methods and might suggest the conditions for a method which would be commercially successful. In the light of the vapor pressure determinations the methods involving the use of a chloride seemed to be most practicable, and glauconite, or greensand, was thought to be the most promising of the natural silicates containing potassium. Hence the first experiments were made with mixtures of greensand and calcium chloride.

\section{VOLATILIZATION OF POTASH FROM MIXTURES OF} GREENSAND AND CAICIUM CHLORIDE

In these experiments a carefully weighed amount of greensand, powdered to pass a 200-mesh sieve, was well mixed in a small platinum boat with approximately 10 per cent of its weight of powdered, anhydrous, C. P. calcium chloride. The boat and contents were heated in the vapor pressure apparatus in a current of nitrogen dried with calcium chloride, as has been described under the determination of the vapor pressure of potassium chloride.

Irregular results obtained at $1200^{\circ} \mathrm{C}$. were thought 
to be due to the temperature being too low for complete fusion and rapid intermingling of the reacting substances. At $1300^{\circ}$ the results of duplicate determinations agreed better, and the amount of potassium chloride volatilized varied with changes in the speed of the gas stream in such manner that it was possible to plot the partial pressures and obtain the vapor pressure of potassium chloride in the mixture. The value of $1.6 \mathrm{~mm}$. of mercury thus obtained at $1300^{\circ}$ bore, however, no apparent relation to the known vapor pressure of potassium chloride or to the amount of potassium in the mixture. The percentage of $\mathrm{K}_{2} \mathrm{O}$ volatilized at $1300^{\circ}$ was found to be only slightly greater than at $1200^{\circ}$. On account of the claim of Spackman and Cornwell ${ }^{1}$ that the presence of water vapor in a cement kiln aids in the formation of soluble potassium compounds from potassiumbearing silicates and acid-forming gases, e. $g$., chlorine from the decomposition of chlorides added with the charge, experiments were made in which water vapor was mixed with the nitrogen used in the vapor pressure tube. The results of these experiments show plainly that no advantage in the formation and volatilization of potassium chloride is gained by the use of water vapor with a mixture of calcium chloride and greensand.

The figures obtained with mixtures of greensand and calcium chloride are given in Table $I$.

Table I-Volatimation of Potash from Mixtures of Grennsand

\begin{tabular}{|c|c|c|c|c|c|c|c|}
\hline \multirow{2}{*}{$\begin{array}{l}\text { Expt. } \\
\text { No. }\end{array}$} & \multirow{2}{*}{ Min- } & \multirow{2}{*}{$\begin{array}{l}\text { Temper- } \\
\text { ature } \\
\text { oc. }\end{array}$} & \multirow{2}{*}{$\begin{array}{l}\text { Weight of } \\
\text { Greensand }\end{array}$} & \multirow{2}{*}{$\begin{array}{c}\text { Charge } \\
\text { CaCla }\end{array}$} & \multirow{2}{*}{ Charge } & \multirow{2}{*}{ in } & $\underset{\mathrm{Vol}}{\mathbf{K}_{2} \mathrm{C}}$ \\
\hline & & & & & & & \\
\hline $\begin{array}{l}82 \\
83\end{array}$ & 12 & 1204 & 0.5993 & $\begin{array}{l}0.060 \\
0.075\end{array}$ & & & \\
\hline $\begin{array}{l}8.3 \\
84\end{array}$ & 12 & & $\begin{array}{l}0.67 \\
0.61\end{array}$ & $\begin{array}{l}0.0 \\
0.0\end{array}$ & & & $\begin{array}{l}13 \\
11\end{array}$ \\
\hline 85 & 14 & & 0.5710 & & & & $\begin{array}{l}11 \\
13\end{array}$ \\
\hline 86 & 16 & & 0.7117 & & & & 1 \\
\hline 87 & 15.5 & 120 & 0.66 & & & & 3 \\
\hline 88 & 18 & 130 & 0.63 & & & & 7 \\
\hline 89 & 11 & & 0.60 & & 0.0 & & \\
\hline 90 & 11 & & 0.60 & & & & $\begin{array}{l}15 \\
17\end{array}$ \\
\hline & $\begin{array}{l}18 \\
26\end{array}$ & $\begin{array}{l}301 \\
1302\end{array}$ & $\begin{array}{l}0.6314 \\
0.5819\end{array}$ & & & 0.0 & $\begin{array}{l}17 \\
19\end{array}$ \\
\hline 93 & 26 & 1302 & & & & & \\
\hline 94 & 26 & & & & & & 6 \\
\hline & 26 & & 0.5 & & & & 2 \\
\hline & 16 & & & & & & 1 \\
\hline 97 & 17 & & & & & & 4 \\
\hline $\begin{array}{l}981 \\
991\end{array}$ & $\begin{array}{l}12 \\
12\end{array}$ & $\begin{array}{l}1299 \\
1301\end{array}$ & $\begin{array}{l}0.6235 \\
0.6338\end{array}$ & $\begin{array}{l}0.062 \\
0.063\end{array}$ & $\begin{array}{l}0.0377 \\
0.0384\end{array}$ & $\begin{array}{l}0.0310 \\
0.0333\end{array}$ & \\
\hline
\end{tabular}

1 'The gas used was a mixture of nitrogen and dry steam.

\section{VOLATILIZATION OF POTASH FROM MIXTURES OF} SILICATES WITH LIME

The next experiments were with calcium oxide as a releasing agent. On account of the number of experiments necessary to obtain results which can be plotted and extrapolated to vapor pressures, and on account of the difficulty in finding any definite relation between the vapor pressures of potassium compounds in the mixtures and the vapor pressures of the pure compounds involved, it was decided to run the experiments in duplicate. The speed of the gas stream was varied, but the time of the experiment was kept constant. The results were expressed in terms of the percentage of potassium oxide volatilized. The knowledge of the vapor pressure of the pure potassium compounds involved was then used in interpreting the results. In the experiments. with lime as a releasing agent the mixtures given in Table II were

${ }^{1}$ U. S. Patent 1,202,327 (1916); C. A., 11 (1917), 89. used. The results of heating these mixtures for 11 min. at $1300^{\circ} \mathrm{C}$, are shown in Table III.

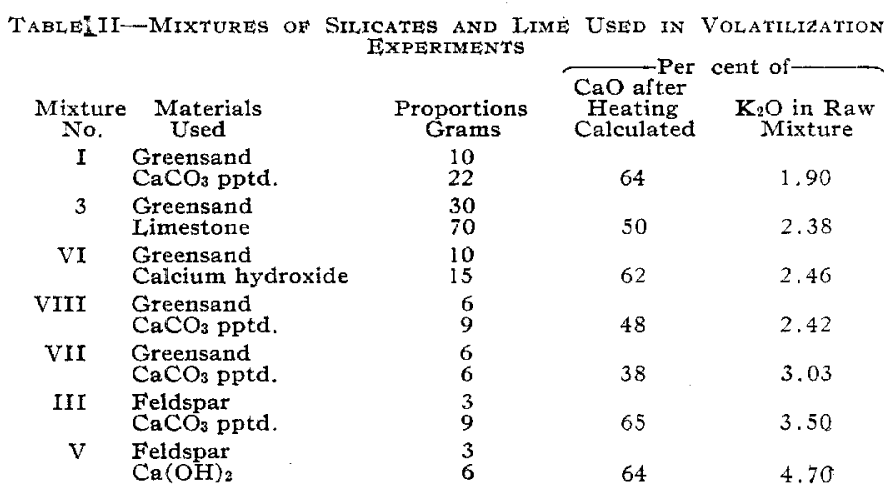

TABLE III-VOIATILIZATION OF POTASH FROM SHICATE aNd IIME;

\begin{tabular}{|c|c|c|c|c|c|c|c|c|}
\hline \multirow{3}{*}{$\begin{array}{l}\text { Expt. } \\
\text { No. }\end{array}$} & \multirow{3}{*}{$\begin{array}{l}\text { Mix- } \\
\text { ture } \\
\text { No. }\end{array}$} & \multirow{3}{*}{$\begin{array}{c}\text { Ce. } N_{2} \\
\text { per } \\
\text { Min. }\end{array}$} & \multirow{3}{*}{$\begin{array}{l}\text { Water } \\
\text { Vapor } \\
\text { Mg. }\end{array}$} & \multirow{3}{*}{$\begin{array}{l}\text { Charge } \\
\text { Grams }\end{array}$} & \multirow{3}{*}{$\begin{array}{c}\text { l.oss } \\
\text { in } \\
\text { Weight } \\
\text { Per } \\
\text { cent }\end{array}$} & \multicolumn{2}{|c|}{$-\mathrm{Mg}_{\mathrm{g}} \mathrm{K}_{2} \mathrm{O}-$} & $\begin{array}{l}\text { cent } \\
\mathrm{K}=\mathrm{C}\end{array}$ \\
\hline & & & & & & in & Resi- $_{\text {in }}$ & $\begin{array}{l}\text { Vol } \\
\text { atiil }\end{array}$ \\
\hline & & & & & & & & \\
\hline 100 & I. & 150 & $\cdots$ & 0.5754 & 34.9 & 10.9 & 2.7 & 75 \\
\hline & & 79 & $\cdots$ & $\begin{array}{l}0.5727 \\
0.5529\end{array}$ & $\begin{array}{l}34.9 \\
35.0\end{array}$ & $\begin{array}{l}10.9 \\
10.5\end{array}$ & & 75 \\
\hline 106 & $\mathrm{I}$ & 150 & 10.9 & 0.5502 & 35.2 & 10.5 & 1.0 & 1 \\
\hline $\begin{array}{l}107 \\
108\end{array}$ & $\frac{1}{I}$ & $\begin{array}{r}117 \\
80\end{array}$ & $\begin{array}{l}7.8 \\
6.0\end{array}$ & $\begin{array}{l}0.5695 \\
0.5839\end{array}$ & $\begin{array}{l}35.2 \\
35.2\end{array}$ & $\begin{array}{l}10.8 \\
11.1\end{array}$ & $1 . \frac{1}{1.2}$ & $\begin{array}{l}90 \\
89\end{array}$ \\
\hline 150 & 3 & 162 & & 0.5588 & 32.9 & 13.3 & 9.3 & 30 \\
\hline & 3 & 134 & & 0.5390 & 33.0 & 12.8 & & 23 \\
\hline & 3 & 163 & 8.2 & 0.5242 & 33.5 & 12.5 & & 1 \\
\hline & 3 & 132 & 7.2 & 0.5062 & 33.6 & 12.1 & 5.5 & 55 \\
\hline 116 & $\mathrm{VI}$ & 161 & ... & 0.5032 & 19.9 & 12.4 & 7.4 & 40 \\
\hline 122 & $\begin{array}{l}V I \\
V I\end{array}$ & $\begin{array}{l}135 \\
161\end{array}$ & 13.7 & $\begin{array}{l}0.4971 \\
0.5362\end{array}$ & 20.0 & 13.2 & $\begin{array}{l}0.8 \\
5.8\end{array}$ & $\begin{array}{l}46 \\
55\end{array}$ \\
\hline 148 & viII & 160 & & 0.4763 & 30.6 & 11.6 & 10 & \\
\hline & VIII & 160 & 19.9 & 0.4732 & & 11.4 & 10. & 1 \\
\hline & VII & 160 & & & & & & \\
\hline & VII & 160 & 5.8 & & & 13 & & \\
\hline & III & 162 & … & & & & & \\
\hline & III & $\begin{array}{l}134 \\
158\end{array}$ & $\because 6$ & $\begin{array}{l}0.30 \\
0.30\end{array}$ & & & & \\
\hline & III & 1.33 & 6.6 & 0.30 & 34 & 10.7 & 0,4 & \\
\hline & Y & 164 & & 430 & & & & \\
\hline & $\mathrm{V}$ & & & & & & & \\
\hline & $\mathrm{V}$ & 146 & 11.1 & 0.3116 & 18.13 & 15.7 & 13. & 14 \\
\hline
\end{tabular}

A consideration of the results of the experiments given in Table III leads to the following conclusions:

(1) The low volatilization in the feldspar mixture (III) is due to the fact that the vapor pressure of potassium oxide alone is too low at $1300^{\circ} \mathrm{C}$. to cause rapid and complete volatilization of the potassium in the mixture. The vapor pressure of potassium oxide from potassium carbonate has been found to be $1.68 \mathrm{~mm}$. at $970^{\circ} \mathrm{C}$ and $5.0 \mathrm{~mm}$. at $1130^{\circ}$, while the vapor pressure of potassium chloride at these temperatures is $10.1 \mathrm{~mm}$. and $52.7 \mathrm{~mm}$., respectively. If the vapor pressure curve for potassium oxide in potassium carbonate has the same general form as that for the chloride, the vapor pressure of the oxide at $1300^{\circ} \mathrm{C}$. would be about $13 \mathrm{~mm}$. It would seem that the vapor pressure of potassium oxide in the highly limed mixture of silicate and lime is not greater than that of potassium oxide in the carbonate, and has probably about the same value as the vapor pressure of water at $15^{\circ} \mathrm{C}$

(2) The explanation of the higher results in the greensand mixture (I) lies in the fact that greensand is a hydrated silicate. Accordingly, any $\mathrm{K}_{2} \mathrm{O}$ formed by the action of $\mathrm{CaO}$ upon the greensand is formed in the presence of water vapor which is being evolved from the silicate. This affords an excellent opportunity for the formation of potassium hydroxide, proyided the reaction

$$
\mathrm{K}_{2} \mathrm{O}+\mathrm{H}_{2} \mathrm{O} \longrightarrow 2 \mathrm{KOH}
$$

is not completely reversed at $1300^{\circ} \mathrm{C}$. The statements of Deville, ${ }^{1}$ quoted by Roscoe and Schorlemmer, ${ }^{2}$ and of Watts $^{3}$

${ }_{1}$ Compt. vend., 45 (1857), 857.

2 Roscoe and Schorlemmer, "Treatise on Chemistry," Vol. II, "The Metals," 1907, 321.

${ }^{3}$ Watts: "Dictionary of Chemistry," Vol. IV, 1868, 702. 
are contradictory on this point, but it is believed that at a temperature of $1300^{\circ}$, or lower, the reaction of $\mathrm{K}_{2} \mathrm{O}$ and $\mathrm{H}_{2} \mathrm{O}$ to form potassium hydroxide must certainly take place at a speed which is not inappreciable. Now the vapor pressure of potassium hydroxide at $800^{\circ} \mathrm{C}$. has been determined and found to be about as great as that of the chloride at $950^{\circ}$ and considerably greater than that of the oxide from the carbonate at $1130^{\circ}$. At $1300^{\circ}$ the vapor pressure of potassium chloride is $202 \mathrm{~mm}$., and at this temperature the hydroxide must be near its boiling point. Hence it is believed that when the greensand molecule reacts with calcium oxide at the high temperature of these experiments, a considerable portion of the potassium in the greensand forms potassium hydroxide with the oxygen and hydrogen which are combined in the silicate, and is thus volatilized from the mixture. In an attempt to aid the volatilization of potassium from the greensand and feldspar before the theory 0 ? the volatilization as given above had been fully developed, some experiments were made in which calcium hydroxide was substituted for calcium carbonate in the mixtures ( $V$ and VI). The use of calcium hydroxide did not aid the volatilization and it is not to be expected that it would, for this compound is dissociated into calcium oxide and water vapor so rapidly at the high temperature of the experiments and the water vapor is so quickly carried away from the mixture by the rapid stream of dry nitrogen used that there is little chance for the formation of potassium hydroxide. On the other hand, the water vapor from greensand is given off rather slowly, and since the hydrogen and oxygen exist closely associated with the potassium in the greensand molecule there is every chance for the formation and volatilization of potassium hydroxide.

(3) The results of the experiments in which nitrogen carrying a considerable amount of water vapor was used instead of dry nitrogen confirm in a very striking manner this new theory of the volatilization of potassium from mixtures of silicates with lime in about the proportions used in the manufacture of portland cement. According to the theory, the low volatilization of potassium from the feldspar and lime mixtures is due to the low vapor pressure of potassium oxide formed by interaction of the potassium aluminium silicate and calcium oxide, and the higher volatilization of the potassium from the greensand and lime mixtures is on account of the high vapor pressure of potassium hydroxide, which is formed along with potassium oxide by the action of calcium oxide on the hydrated potassium iron silicate. The potassium hydroxide thus formed may be dissociated at this high temperature, possibly according to the reaction:

\section{$2 \mathrm{KOH} \rightleftharpoons \mathrm{K}_{2} \mathrm{O}+\mathrm{H}_{2} \mathrm{O}$}

Hence it would be expected that a continuous and fairly large supply of water vapor in the atmosphere of the reaction chamber would prevent to some extent the dissociation of the potassium hydroxide and aid in the volatilization of potassium from the mixture. It would also be expected that the water vapor thus supplied would react to form hydroxide with the potassium oxide in the feldspar mixtures and increase the volatilization of potassium from these mixtures as well. The results of the experiments in which water vapor was used completely fulfilled these expectations, and thus confirmed the theory of the volatilization of potassium as developed above.

(4) The percentage of potassium volatilized from the mixture (3) of greensand with limestone is lower than that obtained when either precipitated calcium carbonate or calcium hydroxide was used. This is probably due partly to the lower lime content of the mixture and partly to impurities present in the limestone. Even in this mixture, however, the volatilization was doubled by the use of water vapor.

(5) The very low volatilization of potassium in the greensand mixtures (VII and VIII) is due partially to the small percentage of lime in the mixtures, but mainly to the fact that these low lime mixtures at this temperature fuse completely, forming a glass in which the potassium is probably combined with the silica and thus dissolved in the other liquid silicates so that it is prevented from volatilizing both by being chemically combined in a rather nonvolatile compound and by being dissolved in a viscous liquid. Undoubtedly the small amount which was volatilized came off during the melting of the mixture. Naturally when potassium is held in a glassy silicate, water vapor cannot aid in its volatilization.

\section{VOLATILIZATION OF POTASH FROM MIXTURES OF} SILICATES WITH LIME AND CALCIUM CHLORIDE

From our knowledge of the vapor pressures of the compounds involved it might be predicted that better results would be obtained in the volatilization of potassium from silicate mixtures containing both lime and calcium chloride, than from mixtures of silicates with either of these compounds alone.

In the experiments to test the efficiency of calcium chloride as a volatilizing agent when used in conjunction with lime as a releasing agent, the mixtures given in Table IV were used. Both were made in proportions which would give, after heating, a residue that approached portland cement in composition.

\begin{tabular}{|c|c|c|c|c|}
\hline TABLE & MIXTURES OF & $\begin{array}{l}\text { ICATES WITH } \\
\text { IUM CHLORI }\end{array}$ & CALCIUM C & BONATE AND \\
\hline $\begin{array}{l}\text { Mixture } \\
\text { No. }\end{array}$ & $\begin{array}{c}\text { Materials } \\
\text { Used }\end{array}$ & $\begin{array}{c}\text { Proportions } \\
\text { Grams }\end{array}$ & $\begin{array}{l}\text { CaO after } \\
\text { Heating } \\
\text { Calculated }\end{array}$ & $\begin{array}{c}\mathrm{K}_{2} \mathrm{O} \text { in Raw } \\
\text { Mixture }\end{array}$ \\
\hline II & $\begin{array}{l}\text { Greensand } \\
\text { CaCOs pptd. } \\
\mathrm{CaCl}_{2} \text { anhyd. }\end{array}$ & $\begin{array}{r}10 \\
21 \\
1\end{array}$ & 65 & 1.90 \\
\hline IV & $\begin{array}{l}\text { Feldspar } \\
\mathrm{CaCO}_{3} \text { pptd. } \\
\mathrm{CaCl}_{2} \text { anhyd. }\end{array}$ & $\begin{array}{r}10 \\
26 \\
2\end{array}$ & 65 & 3.70 \\
\hline
\end{tabular}

The results of heating these mixtures for $11 \mathrm{~min}$. at $1215^{\circ}$ and at $1300^{\circ} \mathrm{C}$. are given in Table V. The experiments with the greensand mixture at $1300^{\circ}$ were made first. Since the volatilization was practically complete at this temperature, the experiments at $1215^{\circ}$ were performed so as to find whether the use of water vapor had any influence on the volatilization of potash from cement mixtures when used in connection with a chloride.

TABle V-Volatilization of Pótash From Mixtures of Strotcata (Heated 11 Min. with 125 to $170 \mathrm{Cc}$, of Nitrogen Passing per Min.)

\begin{tabular}{|c|c|c|c|c|c|c|c|c|}
\hline $\begin{array}{c}\text { Expt. } \\
\text { No. }\end{array}$ & $\begin{array}{l}\text { Mix- } \\
\text { ture } \\
\text { No. }\end{array}$ & $\begin{array}{l}\text { Tem- } \\
\text { pera- } \\
\text { tirre } \\
{ }^{\circ} \mathrm{C} .\end{array}$ & $\begin{array}{c}\text { Water } \\
\text { Vapor } \\
\text { Mg. }\end{array}$ & $\begin{array}{l}\text { Charge } \\
\text { Grams }\end{array}$ & $\begin{array}{c}\text { Loss } \\
\text { in } \\
\text { Weight } \\
\text { Per } \\
\text { cent }\end{array}$ & $\begin{array}{c}-\mathrm{Mg} . \\
\text { in } \\
\text { Charge }\end{array}$ & $\begin{array}{c}\mathrm{K}_{2} \mathrm{O}- \\
\text { in } \\
\text { Resi- } \\
\text { due }\end{array}$ & $\begin{array}{l}\text { Per } \\
\text { cent } \\
\mathrm{K}_{2} \mathrm{O} \\
\text { Vola- } \\
\text { tilizer }\end{array}$ \\
\hline $\begin{array}{l}103 \\
104 \\
105\end{array}$ & $\begin{array}{l}\text { II } \\
\text { II } \\
\text { II }\end{array}$ & $\begin{array}{l}1300 \\
1300 \\
1300\end{array}$ & $\ldots$ & $\begin{array}{l}0.5603 \\
0.5618 \\
0.5629\end{array}$ & $\begin{array}{l}36.0 \\
35.9 \\
36.1\end{array}$ & $\begin{array}{l}10.7 \\
10.7 \\
10.7\end{array}$ & $\begin{array}{l}0.3 \\
0.3 \\
0.2\end{array}$ & $\begin{array}{l}97 \\
97 \\
98\end{array}$ \\
\hline $\begin{array}{l}109 \\
110 \\
111\end{array}$ & $\begin{array}{l}\text { II } \\
\text { II } \\
\text { II }\end{array}$ & $\begin{array}{l}1300 \\
1300 \\
1300\end{array}$ & $\begin{array}{r}10.9 \\
12.0 \\
8.1\end{array}$ & $\begin{array}{l}0.5132 \\
0.5551 \\
0.5350\end{array}$ & $\begin{array}{l}36.2 \\
36.2 \\
36.2\end{array}$ & $\begin{array}{r}9.8 \\
10.5 \\
10.2\end{array}$ & $\begin{array}{l}0.3 \\
0.3 \\
0.2\end{array}$ & $\begin{array}{l}97 \\
97 \\
98\end{array}$ \\
\hline $\begin{array}{l}132 \\
133\end{array}$ & $\begin{array}{l}\text { II } \\
\text { II }\end{array}$ & $\begin{array}{l}1215 \\
1215\end{array}$ & $\ldots$ & $\begin{array}{l}0.5223 \\
0.5301\end{array}$ & $\begin{array}{l}36.2 \\
36.2\end{array}$ & $\begin{array}{r}9.9 \\
10.1\end{array}$ & $\begin{array}{c}0.7 \\
\text { Trace }\end{array}$ & 92 \\
\hline $\begin{array}{l}134 \\
135\end{array}$ & $\begin{array}{l}\text { II } \\
\text { II }\end{array}$ & $\begin{array}{l}1215 \\
1215\end{array}$ & $\begin{array}{r}7.4 \\
15.6\end{array}$ & $\begin{array}{l}0.5301 \\
0.5257\end{array}$ & $\begin{array}{l}36.2 \\
36.2\end{array}$ & $\begin{array}{l}10.1 \\
10.0\end{array}$ & $\begin{array}{l}0.8 \\
0.4\end{array}$ & $\begin{array}{l}92 \\
96\end{array}$ \\
\hline $\begin{array}{l}136 \\
137\end{array}$ & $\begin{array}{l}\text { IV } \\
\text { IV }\end{array}$ & $\begin{array}{l}1215 \\
1215\end{array}$ & $\ldots$ & $\begin{array}{l}0.3249 \\
0.3056\end{array}$ & $\begin{array}{l}36.8 \\
36.9\end{array}$ & $\begin{array}{l}12.0 \\
11.3\end{array}$ & $\begin{array}{l}3.5 \\
3.1\end{array}$ & 71 \\
\hline $\begin{array}{l}138 \\
139\end{array}$ & $\begin{array}{l}\text { IV } \\
\text { IV }\end{array}$ & $\begin{array}{l}1215 \\
1215\end{array}$ & $\begin{array}{r}13.7 \\
7.3\end{array}$ & $\begin{array}{l}0.3021 \\
0.3149\end{array}$ & $\begin{array}{l}36.9 \\
36.9\end{array}$ & $\begin{array}{l}11.2 \\
11.6\end{array}$ & $\begin{array}{l}2.9 \\
3.0\end{array}$ & $\begin{array}{l}74 \\
74\end{array}$ \\
\hline
\end{tabular}

The results of the experiments on mixtures of greensand and of feldspar with both calcium oxide and calcium chloride in proportions to give a residue which has about the composition of portland cement show that:

(1) The removal of potassium by volatilization from the greensand mixture is practically complete in $11 \mathrm{~min}$. at a temperature as low as $1215^{\circ} \mathrm{C}$, but the volatilization of potassium from the feldspar mixture is not as complete. 
(2) As might be expected, no advantage is gained by the use of water vapor when there is present in the mixture sufficient chlorine as chloride to form with the potassium of the silicate the stable compound potassium chloride, whose vapor pressure, $101 \mathrm{~mm}$. at $1215^{\circ} \mathrm{C}$. and $202 \mathrm{~mm}$. at $1300^{\circ} \mathrm{C}$, is high enough to allow of rapid evaporation.

(3) The claims made by Spackman and Cornwell ${ }^{1}$ that the presence of water vapor aids in the formation of potassium chloride from chlorides and potassium-bearing silicates appear to be unfounded.

VOLATILIZATION OF POTASH FROM LOW LIME SILICATECHLORIDE MIXTURES

In the previous experiments we had learned: first, that potash is volatilized at a lower temperature and more rapidly from greensand mixtures than from feldspar mixtures; and, second, that the volatilization of potash from low lime mixtures which fuse is slight. It was surmised, however, that in the latter case the low volatilization was due rather to the fusion of the mixture than to the lack of lime to set free the potash from the silicate.

A series of experiments was therefore run using mixtures of greensand with a chloride and with limestone in much smaller proportions than the proportion of limestone used in portland cement mixtures. In these experiments the mixtures given in Table VI were used.

\begin{tabular}{|c|c|c|c|c|c|}
\hline \multirow{3}{*}{$\begin{array}{l}\text { Mixture } \\
\text { No. } \\
5\end{array}$} & \multirow{2}{*}{$\begin{array}{c}\text { ABI,F VI-Low L, } \\
\text { Materials } \\
\text { Used }\end{array}$} & \multirow{2}{*}{$\begin{array}{l}\text { ME GREENSAN } \\
\text { Proportions } \\
\text { Grams }\end{array}$} & \multirow{2}{*}{$\begin{array}{l}\text { ND-CHLORIDE } \\
\text { Ratio of } \\
\text { Greensand } \\
\text { I, imestone }\end{array}$} & \multicolumn{2}{|c|}{$\begin{array}{l}\text { Mixruras } \\
\text { - Percentage of- }\end{array}$} \\
\hline & & & & $\begin{array}{c}\text { Chloride } \\
\text { Added }\end{array}$ & $\begin{array}{l}\mathrm{K}_{2} \mathrm{O} \text { in } \\
\text { Mixture }\end{array}$ \\
\hline & $\begin{array}{l}\text { Greensand } \\
\text { Limestone }\end{array}$ & $\begin{array}{l}50 \\
50\end{array}$ & $1: 1$ & None & 3.85 \\
\hline 7 & $\begin{array}{l}\text { Greensand } \\
\text { Limestone } \\
\text { Sodium chloride }\end{array}$ & $\begin{array}{r}10 \\
10 \\
1\end{array}$ & $1: 1$ & 5.0 & 3.67 \\
\hline 8 & $\begin{array}{l}\text { Greensand } \\
\text { Limestone } \\
\text { Calcium chloride }\end{array}$ & $\begin{array}{l}10 \\
10 \\
0.9\end{array}$ & $1: 1$ & 4.5 & 3.69 \\
\hline 9 & $\begin{array}{l}\text { Greensand } \\
\text { Limestone } \\
\text { Sodium chloride }\end{array}$ & $\begin{array}{l}20 \\
10 \\
2,1\end{array}$ & $2: 1$ & 7.0 & 4.75 \\
\hline 10 & $\begin{array}{l}\text { Greensand } \\
\text { Limestone } \\
\text { Sodium chloride }\end{array}$ & $\begin{array}{l}20 \\
10 \\
0.9\end{array}$ & $2: 1$ & 3.0 & 4.95 \\
\hline
\end{tabular}

The results of heating these mixtures at temperatures just below those at which they start to fuse are given in Table VII.

Table VII-Volatilization of POTASH from Low lime Greensand-

\begin{tabular}{|c|c|c|c|c|c|c|c|c|c|c|c|}
\hline \multirow{4}{*}{ 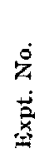 } & \multirow{4}{*}{$\begin{array}{l}\dot{0} \\
z \\
\dot{z} \\
z\end{array}$} & \multirow{4}{*}{ 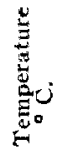 } & \multicolumn{2}{|c|}{ - Ratio } & \multicolumn{2}{|c|}{ Chloride } & \multirow{4}{*}{$\begin{array}{l}0 \\
5 \\
5 \\
\\
\end{array}$} & \multirow{4}{*}{ 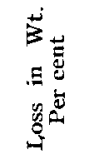 } & \multicolumn{2}{|c|}{ Potassium } & \multirow{4}{*}{ 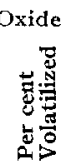 } \\
\hline & & & $E$ & そ) & & & & & & $\mathscr{\Xi}$ & \\
\hline & & & & 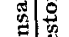 & & ]ี & & & & & \\
\hline & & & $\underline{E}$ & 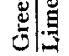 & $\vec{B}$ & $\stackrel{\Delta}{2}$ & & & & $\Xi$ & \\
\hline 155 & 5 & 1050 & 60 & $1: 1$ & & & 0.4419 & 25.1 & 17.0 & 17.2 & \\
\hline & 5 & & 30 & $1: 1$ & & & & & & & \\
\hline - & 5 & 117 & 30 & $1: 1$ & & & & 25.45 & & & \\
\hline & 7 & 105 & 60 & $1: 1$ & $\mathrm{NaC}$ & 5.0 & & 30. & & & \\
\hline & 7 & & & $1: 1$ & & & & & & & \\
\hline & 7 & 120 & 15 & $1: 1$ & $\mathrm{Na}$ & 5. & & 31. & & & \\
\hline & 7 & & 15 & $1: 1$ & & & & & & & \\
\hline & 8 & & 15 & $1: 1$ & & & & & & & \\
\hline & 9 & & 15 & $2: 1$ & & & & & & & \\
\hline & 10 & 1170 & 15 & $2: 1$ & & 3.0 & 0.4260 & 24,25 & 21.1 & 8.1 & \\
\hline
\end{tabular}

A consideration of the results given in Table VII shows that:

(1) The volatilization of potash from a 1:1 mixture of greensand and limestone without the addition of a chloride is very small at temperatures up to $1170^{\circ} \mathrm{C}$. This is true even in the presence of water vapor which was used in Expt. 163.

(2) On addition of a chloride in proportion slightly greater than that calculated for the formation of potassium chloride,

\footnotetext{
1 Loc. cit.
}

the potash in greensand and limestone mixtures can be readily volatilized at temperatures slightly lower than the temperatures at which the mixtures begin to fuse. This has been shown for mixtures containing as little as one-third limestone.

(3) Sodium chloride appears to be somewhat more efficient than calcium chloride as a volatilizing agent, and when less chloride is used than the amount calctlated to give potassium chloride with all of the potassium in the mixture there is a decided decrease in the volatilization.

\section{SUMMARY}

1-In the application of a knowledge of the vapor pressures of potassium compounds to a study of the volatilization of potash from silicate mixtures, a new theory involving the high vapor pressure of potassium hydroxide has been advanced to explain the volatilization of potassium from silicate and lime mixtures. This theory is supported by thefact that greensand which contains the elements of water loses its potassium by volatilization very much more readily than feldspar, and by the fact that when water vapor is present to aid in the formation of potassium hydroxide, the volatilization of potassium from high lime mixtures is greatly increased in every case.

2-Experiments on a mixture of feldspar with calcium chloride and lime in the proportions necessary to give a portland cement clinker, and on a mixture of glauconite with lime and calcium chloride, show that the potash is volatilized from both silicates at temperatures as low as $1215^{\circ} \mathrm{C}$. The potash is, however, more readily volatilized from the glauconite than from the feldspar.

3-It has been shown that when a chloride is used in the volatilization of potash no advantage is gained by the use of water vapor. This is in accord with what might be expected, since the chloride of potassium is so much more stable at high temperatures than the hydroxide, and is contrary to the patent claims of Spackman and Cornwell.

4-Experiments on mixtures of greensand with a chloride in the proportion calculated to give potassium chloride and limestone in proportions much lower than those used in portland cement mixtures show that the potash can be readily volatilized from mixtures containing as little as one-third of limestone, provided the mixture is heated at a temperature slightly below its fusing point.

\section{Examination for Pyrotechnic Assistant}

The United States Civil Service Commission has announced an examination for pyrotechnic assistant at $\$ 1872$ a year to fill a vacancy at Picatinny Arsenal, Dover, N. J., and other vacancies requiring similar qualifications. The duties of the appointee will be to assist in the development of design, test, and manufacture of military pyrotechnics and in addition the duties of an observer and firer from aircraft. Competitors will be rated on (1) physical ability, 40; (2) education, experience, and fitness, 60. Applicants must be high school graduates and have had one year's experience along the line of pyrotechnic material. Experience in flying and acquaintance with the present equipment and devices of the Aircraft Divisions of the War Department are desirable. Applications should be filed with the United States Civil Service Commission, Washington, D. C., prior to the hour of closing business on April 5, 1921. 